\title{
Growth and Biochemical Characterization of Olive (Olea europaea L., cv. Raja) Callus Cultures Differing in Proliferation Pattern
}

\author{
Valentina Iori \\ Institute of Agro-environmental and Forest Biology (IBAF) \\ CNR - National Research Council of Italy, Via Salaria Km. 29,300 \\ 00015 Monterotondo Scalo (Roma), Italy \\ E-mail: valentina.iori@ibaf.cnr.it
}

Massimo Zacchini (Corresponding author)

Institute of Agro-environmental and Forest Biology (IBAF)

CNR - National Research Council of Italy, Via Salaria Km. 29,300

00015 Monterotondo Scalo (Roma), Italy

Tel: 39-069-067-2540 Fax: 39-069-067-2990. E-mail: massimo.zacchini@ibaf.cnr.it

Received: August 4, 2014 Accepted: September 4, 2014 Published: September 9, 2014

Doi: 10.5296/jab.v3i1.6064 URL: http://dx.doi.org/10.5296/jab.v3i1.6064

\begin{abstract}
Olive is the most diffused fruit crop in the Mediterranean region, and the improvement of its productivity by conventional and biotechnological approaches is currently required. In vitro cultures have been proven to be very useful for this purpose. In this work, callus cultures of olive (Olea europaea L., cv. Raja) were established from basal tissues of nodal explants and subcultured on OM medium in a growth chamber at $25^{\circ} \mathrm{C}$ with a 16 h-light photoperiod. Cell clusters with different morphological aspect originated from culture, giving rise to two distinct callus lines that were isolated and long subcultured. Growth and biochemical analyses were then performed to characterize the different proliferation pattern of the two olive callus lines. Compact-type proliferating cultures showed lower growth ability, evaluated by relative growth rate (RGR), than friable-type ones. At biochemical level, differences in pigment, oxidative stress and antioxidative defense marker contents between the two callus
\end{abstract}


lines were observed. In particular, higher chlorophyll and total carotenoid content, higher hydrogen peroxide content and antioxidative enzyme (ascorbate peroxidase, APX, EC 1.11.1.11; glutathione reductase, GR, EC 1.6.4.2; catalase, CAT, EC 1.11.1.6) activities were observed in compact-type proliferating cultures compared to friable ones. On the contrary, at polyamine (PA) level, a higher putrescine (Put) content was detected in the friable-type proliferating cultures. Results evidenced that proliferation of olive callus cells can be characterized by different features involving morphological aspects and biochemical traits associated to cell oxidative condition.

Keywords: Antioxidants, Growth rate, in vitro culture, Oxidative stress, Pigments, Polyamines

\section{Introduction}

In vitro culture has been long recognized as very useful to support olive genetic improvement, as conventional techniques are limited by the long juvenile phase and the high level of heterozigosity characterizing this fruit crop. In this context, several authors highlighted the possibility of applying to olive the in vitro techniques such as micropropagation (Rugini, 1984; Zacchini \& de Agazio, 2004a), somatic embryogenesis (Rugini \& Caricato, 1995; Trabelsi et al., 2011), callus and suspension cell culture (Shibli \& Al-Juboory, 2002; Gentile $\&$ Uccella, 2014). Moreover, somaclonal variation and transformation to obtain olive genetic improvements have been reported (Rugini et al., 2000). A particular attention has been paid to the callus culture technique for characterizing stress tolerant cultivars (Shibli \& Al-Juboory, 2002) and studying bioactive compound production (Saimaru et al., 2007; Gentile \& Uccella, 2014). Olive callus is considered a good model system to study different aspects of fatty acid and lipid metabolism (Williams et al., 1998, 2000; Ramli et al., 2002; Hernandez et al., 2008), as it has been reported that olive callus cells have an acyl lipid composition that is comparable to developing fruit (Williams et al., 1993). Nevertheless, few information is available in literature about morphological and biochemical characteristics related to olive callus cell proliferation. Williams et al. (2000) suggested an involvement of lipoxygenase (LOX) in the growth of olive callus cultures, discussing also the possible interaction between some in vitro culture factors, such as wounding and the presence of exogenous plant growth regulators, and the products of the LOX pathway. In this regard, it has been highlighted that in vitro microenvironmental and culture factors, and their interactions, can act as stress agents (Gaspar et al., 2002, Hazarika 2006), generating reactive oxygen species (ROS) and oxidative stress processes (Grzelak et al., 2001).

Oxidative stress has been considered as promoting some physiological and genetic disorders in in vitro grown plant tissues, such as hyperhydricity (Frank et al., 1995), somaclonal variability (Cassel \& Curry, 2001) and loss of totipotency (Benson, 2000a). Moreover, initiation and maintenance of a cancerous state of cells, characterized for a progressive loss of organogenic competence, have been attributed to a permanent oxidative stress (Gaspar et al., 2002). In vitro stress factors, such as free radical production, are co-responsible for tissue culture recalcitrance, a phenomenon that has been usually recognized as a limiting factor for a biotechnological approach to plant genetic improvement (Benson, 2000b), especially for woody plant system and monocotyledonous species. On the contrary, antioxidative stress 
response represents an adaptive strategy that can be beneficial to improve the establishment and the growth of the plant cell culture (Bat'ková et al., 2008). For these reasons, the evaluation of the cell oxidative condition can be very relevant to characterize the adaptation of plant cells to the in vitro culture.

The aim of this work was to characterize two olive callus lines, differing in proliferation pattern, for growth and biochemical markers associated to oxidative stress and antioxidative response. The oxidative status of olive callus cells was investigated by measuring membrane lipid peroxidation (malondialdehyde assay, MDA) and hydrogen peroxide content. The antioxidant defense response was evaluated by analyzing both carotenoids and PA content, and the activity of antioxidant enzymes such as APX, GR, CAT, and guaiacol peroxidase (GPX, EC 1.11.1.7).

\section{Materials and Methods}

\subsection{Plant Material and Culture Conditions}

Branches of olive cultivar Raja were collected in winter from fifty-year-old field-grown plants. Current-year shoots were defoliated, cut in $3 \mathrm{~cm}$ long nodal segments and washed for $30 \mathrm{~min}$ in running tap water. Nodal segments were subjected to sterilization by immersion in $0.1 \% \mathrm{HgCl}_{2}$ for $5 \mathrm{~min}$, washing in sterile distilled water, then immersion in $15 \%$ commercial bleach $(7 \%$ of active $\mathrm{Cl})$ for $15 \mathrm{~min}$ and washing again three times in sterile distilled water. Nodal segments were then transferred to the initial culture medium consisting in half-strength MS medium supplemented with $36 \mathrm{~g} \mathrm{l}^{-1}$ mannitol, $4.56 \mu \mathrm{M}$ zeatin, antibiotics $\left(0.5 \mathrm{~g} \mathrm{l}^{-1}\right.$ carbenicillin disodium and $0.1 \mathrm{~g} \mathrm{l}^{-1}$ cefotaxime sodium) and cultured in glass tubes for a month in a growth chamber at $24^{\circ} \mathrm{C}$ with a 16h-light photoperiod (photon flux density of 50 $\mu \mathrm{mol} \mathrm{m} \mathrm{sec}^{-1}$ ). Surviving explants were placed in OM proliferation medium (Rugini, 1984) supplemented with $36 \mathrm{~g} \mathrm{l}^{-1}$ mannitol, $13.68 \mu \mathrm{M}$ zeatin, $4.33 \mu \mathrm{M} \mathrm{GA}_{3}$ and $0.49 \mu \mathrm{M}$ IBA. Callus obtained from the basal part of the explants was removed and cultured in petri plates on OM medium supplemented with $36 \mathrm{~g} \mathrm{l}^{-1}$ mannitol, $4.56 \mu \mathrm{M}$ zeatin and 4.52 $\mu \mathrm{M}$ 2,4-D. Culture media were adjusted to $\mathrm{pH} 5.8$ before autoclaving at $121{ }^{\circ} \mathrm{C}$ for $25 \mathrm{~min}$ and solidified with $0.8 \%$ agar. Antibiotics were added filter-sterilized to the culture medium after autoclaving. Culture was maintained in a growth chamber at $25{ }^{\circ} \mathrm{C}$ with a $16 \mathrm{~h}$-light photoperiod (photon flux density of $50 \mu \mathrm{mol} \mathrm{m} \mathrm{sec}^{-1}$ ).

\subsection{Growth and Pigment Analysis}

Relative growth rate (RGR) was calculated according to Galiba et al. (1993). Chlorophyll and carotenoid contents were measured in methanolic extracts following the method of Wellburn (1994). Briefly, the absorbance of aliquots of supernatant obtained by several centrifugations (15000 x $g$ for $10 \mathrm{~min}$ each) and re-suspensions was read at $470 \mathrm{~nm}, 652.4 \mathrm{~nm}$ and $665.2 \mathrm{~nm}$ in a spectrophotometer (Perkin Elmer, Norwalk, CT, USA). Pigment concentrations were calculated by following the relative equations reported by Lichtenthaler (1987).

\subsection{Enzyme Activity and Protein Content Analysis}

Enzyme extraction was performed on frozen samples using a pre-chilled mortar and pestle 
with 2 vol of an ice-cold extraction buffer $(0.05 \mathrm{M}$ potassium phosphate buffer, $\mathrm{pH} 7.0)$ containing $0.1 \%(\mathrm{w} / \mathrm{v})$ ascorbic acid, $1 \%(\mathrm{w} / \mathrm{v})$ polyvinylpolypyrrolidone, $1 \mathrm{mM} \mathrm{Na} \mathrm{N}_{2}$-EDTA and $0.1 \%(\mathrm{v} / \mathrm{v})$ Triton X-100. The homogenate was centrifuged at $15000 \times g$ for $30 \mathrm{~min}$ at $4{ }^{\circ} \mathrm{C}$ and the supernatant was used for enzyme assays. APX activity was measured according to the method of Nakano and Asada (1981) by following the decrease of absorbance at 290 $\mathrm{nm}$ for $1 \mathrm{~min}$, corresponding to the oxidation of ascorbic acid. APX activity was calculated using its extinction coefficient $\left(2.8 \mathrm{mM}^{-1} \mathrm{~cm}^{-1}\right)$. GR activity was measured following the modified method of Foyer and Hallywell (1976). Assay mixture $(1 \mathrm{ml})$ contained $0.1 \mathrm{ml}$ of 8 $\mathrm{mM} \mathrm{Na} 2$-EDTA, $0.1 \mathrm{ml}$ of $1.5 \mathrm{mM}$ NADPH, $0.1 \mathrm{ml}$ of $5 \mathrm{mM}$ oxidized glutathione (GSSG) in $0.1 \mathrm{M}$ potassium phosphate buffer $(\mathrm{pH} 7.0), 0.63 \mathrm{ml}$ of $0.1 \mathrm{M}$ potassium phosphate buffer (pH 7.0) and $0.07 \mathrm{ml}$ of the crude extract or potassium phosphate buffer (blank). Enzyme activity was evaluated following the decrease of absorbance at $340 \mathrm{~nm}$ for $2 \mathrm{~min}$, corresponding to the oxidation of NADPH, and calculated using the extinction coefficient of $6.22 \mathrm{mM}^{-1} \mathrm{~cm}^{-1}$. CAT activity was measured according to Havir and McHale (1987). Assay mixture $(1 \mathrm{ml})$ contained $0.1 \mathrm{ml}$ of $125 \mathrm{mM} \mathrm{H}_{2} \mathrm{O}_{2}$ and $20 \mu \mathrm{l}$ of the crude extract in $0.05 \mathrm{M}$ potassium phosphate buffer ( $\mathrm{pH}$ 7.0). Enzyme activity was evaluated following the decrease of absorbance at $240 \mathrm{~nm}$ for $40 \mathrm{~s}$ and calculated using the extinction coefficient $(0.036$ $\mathrm{mM}^{-1} \mathrm{~cm}^{-1}$ ). GPX activity was measured according to Chance and Maehly (1955). Assay mixture $\left(1 \mathrm{ml}\right.$ ) contained $0.1 \mathrm{ml}$ of $90 \mathrm{mM}$ guaiacol, $0.1 \mathrm{ml}$ of $125 \mathrm{mM} \mathrm{H}_{2} \mathrm{O}_{2}$ and $10 \mu \mathrm{l}$ of the crude extract in $0.05 \mathrm{M}$ potassium phosphate buffer $(\mathrm{pH}$ 7.0). Enzyme activity was evaluated following the increase of absorbance at $470 \mathrm{~nm}$ for $40 \mathrm{~s}$ and calculated using the extinction coefficient $\left(26.6 \mathrm{mM}^{-1} \mathrm{~cm}^{-1}\right)$. Protein content was measured following the method of Bradford (1976).

\subsection{Lipid Peroxide and Hydrogen Peroxide Content}

The content of lipid peroxides was measured as 2-thiobarbituric acid-reactive metabolites (TBA), following the modified method of Heath and Packer (1968). Frozen samples were homogenized in a pre-chilled mortar and pestle with 2 vol of ice-cold $0.1 \%(\mathrm{w} / \mathrm{v})$ trichloroacetic acid (TCA) and centrifuged for $15 \mathrm{~min}$ at $16000 \mathrm{x}$. Assay mixture containing $1 \mathrm{ml}$ aliquot of supernatant and $2 \mathrm{ml}$ of $0.5 \%(\mathrm{w} / \mathrm{v})$ thiobarbituric acid in $20 \%$ (w/v) trichloroacetic acid (TCA) was heated to $95{ }^{\circ} \mathrm{C}$ for $30 \mathrm{~min}$ and then rapidly cooled in an ice-bath. After centrifugation $\left(10000 \times g\right.$ for $10 \mathrm{~min}$ at $\left.4{ }^{\circ} \mathrm{C}\right)$, the supernatant absorbance $(532 \mathrm{~nm})$ was read and the value corresponding to non-specific absorption $(600 \mathrm{~nm})$ was subtracted. Malondialdehyde (MDA) concentration was calculated using the extinction coefficient $\left(155 \mathrm{mM}^{-1} \mathrm{~cm}^{-1}\right)$.

Hydrogen peroxide content was assayed by the resorcinol-titanium oxide method according to Franck et al. (1998). Frozen samples were homogenized in a pre-chilled mortar and pestle with 3 vol of ice-cold 5\% (w/v) trichloroacetic acid (TCA) and centrifuged for $30 \mathrm{~min}$ at 16 $000 \times g$ at $4{ }^{\circ} \mathrm{C}$. Supernatant was removed, adjusted to $\mathrm{pH} 8.4$ with ammonia solution and divided in $0.3 \mathrm{ml}$ aliquots. To half of these (blanks) $1.2 \mu \mathrm{l}$ of $1 \mathrm{mg} / \mathrm{ml}$ catalase (Sigma, bovine liver, $17000 \mathrm{U} / \mathrm{mg})$ in 30\% (v/v) glycerol and 10\% ethanol (v/v) was added. Blanks and samples without added catalase were incubated at $20{ }^{\circ} \mathrm{C}$ for $10 \mathrm{~min}$. Assay mixture $(1 \mathrm{ml})$ consisting of $0.3 \mathrm{ml}$ blank or sample aliquot, $0.6 \mathrm{ml}$ of $0.1 \mathrm{M}$ potassium phosphate buffer $(\mathrm{pH}$ 
8.4) and $0.3 \mathrm{ml}$ reactive solution $(0.15 \mathrm{ml}$ of $0.6 \mathrm{mM}$ Par 4-[2-pyridilazo]resorcinol $+0.15 \mathrm{ml}$ of $0.6 \mathrm{mM}$ potassium titanium oxalate) was incubated at $45{ }^{\circ} \mathrm{C}$ for $60 \mathrm{~min}$. Sample absorbance $(508 \mathrm{~nm})$ was read and value corresponding to blank was subtracted. $\mathrm{H}_{2} \mathrm{O}_{2}$ concentration was calculated using the extinction coefficient $\left(36 \mathrm{mM}^{-1} \mathrm{~cm}^{-1}\right)$.

\subsection{Analysis of Free Polyamine Content}

Samples were homogenized in 5 vol of a $5 \%(\mathrm{v} / \mathrm{v})$ cold perchloric acid solution in a pre-chilled mortar and pestle. The homogenates were kept for $1 \mathrm{~h}$ at $4{ }^{\circ} \mathrm{C}$ and centrifuged at $16000 \times g$ for $10 \mathrm{~min}$. Aliquots of the supernatant fraction were dansylated (Zacchini \& de Agazio, 2004b) and free amines were separated by HPLC (Beckman-Coulter, Fullerton, CA, USA). Samples were injected on a C18 reverse phase column $(250 \times 4.6 \mathrm{~mm}, 5 \mu$ particle size, Grace Davison, Deerfield, IL, USA) and quantified by a Jasco (mod. FP 2020 Plus, Tokyo, Japan, excitation $360 \mathrm{~nm}$, emission $510 \mathrm{~nm}$ ) fluorescence detector, according to standard curves. Elution was performed with a multi step linear gradient of aqueous acetonitrile (Zacchini \& de Agazio, 2004b). Chromatograms were recorded and integrated by the 32 Karat $^{\mathrm{TM}}$ Software 5.0 (Beckman-Coulter, Fullerton, CA, USA).

\subsection{Statistical Analysis}

All the analyses were performed on at least three replicates. Each replicate consisted in a Petri plate containing 4 calli. Data obtained were subjected to analysis of variance (ANOVA). Tukey's test was used to compare the means at $P \leq 0.05$.

\section{Results}

Olive (Olea europaea L., cv. Raja) callus cultures, obtained from the basal part of nodal explants of young branches, were cultivated on OM medium supplemented with $36 \mathrm{~g} \mathrm{l}^{-1}$ mannitol, $4.56 \mu \mathrm{M}$ zeatin and $4.52 \mu \mathrm{M}$ 2,4-D. During culture, two callus lines with different morphological characteristics, such as proliferation pattern (compact or friable cell cluster type) and color (dark or light green), were selected and maintained. Growth analysis was performed by calculating the RGR (Table 1). Results evidenced that RGR of compact-type calli was more than 4-fold lower than friable-type ones. Regarding the evaluation of the oxidative status markers, no differences in MDA were observed between the callus lines while a significantly higher hydrogen peroxide content was found in compact-type calli (Table 1).

Table 1. Relative growth rate (RGR), lipid peroxide (MDA) content and $\mathrm{H}_{2} \mathrm{O}_{2}$ content in two olive callus lines differing for type of proliferation pattern (compact-type and friable-type). In columns, different letters represent significantly different values (mean \pm S.E., Tukey's test, $P \leq 0.05)$

\begin{tabular}{cccc}
\hline Callus lines & RGR & MDA $\left(\mathrm{nmol}^{-1} \mathrm{FW}\right)$ & $\mathrm{H}_{2} \mathrm{O}_{2}\left(\mathrm{nmol}^{-1} \mathrm{~g}^{-1} \mathrm{FW}\right)$ \\
\hline Compact-type & $8.31( \pm 0.51) \mathrm{b}$ & $2.77( \pm 0.14) \mathrm{a}$ & $9.01( \pm 1.12) \mathrm{a}$ \\
Friable-type & $39.16( \pm 2.12) \mathrm{a}$ & $3.07( \pm 0.22) \mathrm{a}$ & $5.11( \pm 0.34) \mathrm{b}$ \\
\hline
\end{tabular}


As shown in Table 2, total chlorophyll content in compact-type calli was twice than friable-type ones. Both chlorophyll $a$ and chlorophyll $b$ content in compact-type callus cells was markedly higher than in friable-type ones, as well as chlorophyll $a$ /chlorophyll $b$ ratio. Concerning total carotenoids, Table 2 shows that their content was notably higher in compact-type calli compared with friable-type ones.

Table 2. Analysis of total chlorophyll, chlorophyll $a$ and chlorophyll $b$ content, chlorophyll $a$ /chlorophyll $b$ ratio and total carotenoid content in two olive callus lines differing for type of proliferation pattern (compact-type and friable-type). In columns, different letters represent significantly different values (mean \pm S.E., Tukey's test, $P \leq 0.05$ )

\begin{tabular}{cccccc}
\hline Callus lines & $\begin{array}{c}\text { Total Chl } \\
\left(\mu \mathrm{gg}^{-1} \mathrm{FW}\right)\end{array}$ & $\begin{array}{c}\mathrm{Chl} a \\
\left(\mu \mathrm{g} \mathrm{g}^{-1} \mathrm{FW}\right)\end{array}$ & $\begin{array}{c}\mathrm{Chl} b \\
\left(\mu \mathrm{g} \cdot \mathrm{g}^{-1} \mathrm{FW}\right)\end{array}$ & Chl a/b & $\begin{array}{c}\text { Total carotenoids } \\
\left(\mu \mathrm{g} \cdot \mathrm{g}^{-1} \mathrm{FW}\right)\end{array}$ \\
\hline Compact-type & $19.6( \pm 2.3) \mathrm{a}$ & $8.1( \pm 0.9) \mathrm{a}$ & $11.5( \pm 2.1) \mathrm{a}$ & 0.71 & $2.2( \pm 0.3) \mathrm{a}$ \\
Friable-type & $8.3( \pm 0.6) \mathrm{b}$ & $2.7( \pm 0.3) \mathrm{b}$ & $5.6( \pm 0.4) \mathrm{b}$ & 0.48 & $0.4( \pm 0.06) \mathrm{b}$ \\
\hline
\end{tabular}

In compact-type calli antioxidative enzyme activities were higher than in friable-type ones (Table 3), except for GPX. In particular, APX and GR activities were about 100\% higher in compact-type calli as compared to friable-type ones, while CAT activity was about $50 \%$ higher in compact-type calli as compared to friable-type calli. No differences in protein content were detected between callus lines (data not shown).

Table 3. Antioxidative enzymes activities (ascorbate peroxidase, APX, glutathione reductase, GR, catalase, CAT, guaiacol peroxidase, GPX) in two olive callus lines differing for type of proliferation pattern (compact-type and friable-type). In columns, different letters represent significantly different values (mean \pm S.E., Tukey's test, $P \leq 0.05$ )

\begin{tabular}{ccccc}
\hline Callus lines & $\begin{array}{c}\text { APX } \\
\left(\mu \mathrm{mol} \cdot \mathrm{g}^{-1} \mathrm{FW}\right)\end{array}$ & $\begin{array}{c}\mathrm{GR} \\
\left(\mu \mathrm{mol} \cdot \mathrm{g}^{-1} \mathrm{FW}\right)\end{array}$ & $\begin{array}{c}\mathrm{CAT} \\
\left(\mu \mathrm{mol} \cdot \mathrm{g}^{-1} \mathrm{FW}\right)\end{array}$ & $\begin{array}{c}\mathrm{GPX} \\
\left(\mu \mathrm{mol} \cdot \mathrm{g}^{-1} \mathrm{FW}\right)\end{array}$ \\
\hline Compact-type & $38.1( \pm 4.2) \mathrm{a}$ & $0.88( \pm 0.05) \mathrm{a}$ & $0.62( \pm 0.03) \mathrm{a}$ & $29.5( \pm 4.4) \mathrm{a}$ \\
Friable-type & $18.2( \pm 2.2) \mathrm{b}$ & $0.42( \pm 0.02) \mathrm{b}$ & $0.43( \pm 0.03) \mathrm{b}$ & $36.7( \pm 6.8) \mathrm{a}$ \\
\hline
\end{tabular}

As shown in Table 4, Put content was more than 5-fold higher in friable-type calli than in compact-type ones while spermidine and spermine content did not show any difference between the two callus lines. 
Table 4. Free polyamine (Put, putrescine, Spd, spermidine, Spm, spermine) content in two olive callus lines differing for type of proliferation pattern (compact-type and friable-type). In columns, different letters represent significantly different values (mean \pm S.E., Tukey's test, $P \leq 0.05)$

\begin{tabular}{cccc}
\hline Callus lines & $\begin{array}{c}\text { Put } \\
\left(\mathrm{nmol}^{-1} \mathrm{~g}^{-1} \mathrm{FW}\right)\end{array}$ & $\begin{array}{c}\text { Spd } \\
\left(\mathrm{nmol}^{-1} \mathrm{FW}\right)\end{array}$ & $\begin{array}{c}\mathrm{Spm} \\
\left(\mathrm{nmol}^{-1} \mathrm{gW}\right)\end{array}$ \\
\hline Compact-type & $14.5( \pm 2.1) \mathrm{b}$ & $31.8( \pm 4.7) \mathrm{a}$ & $54.4( \pm 7.3) \mathrm{a}$ \\
Friable-type & $83.3( \pm 3.9) \mathrm{a}$ & $25.8( \pm 6.1) \mathrm{a}$ & $46.4( \pm 5.8) \mathrm{a}$ \\
\hline
\end{tabular}

\section{Discussion}

Olive callus culture represents a plant material of notable interest for lipid metabolism studies (Williams et al., 2000; Ramli et al., 2002; Hernandez et al., 2008), biopharmaceutical compound production (Gentile \& Uccella, 2014) and for the genetic improvement of this important fruit crop (Rugini et al., 2000). In this context, the investigation on morphological and biochemical traits associated to cell proliferation pattern can be very useful to ameliorate the growth and the regeneration abilities of the olive tissue cultures, with a particular regard to in vitro recalcitrant genotypes. In literature, evidences are reported that the oxidative status of cells can affect the growth capability of the tissue cultures (Cassells \& Curry, 2001; Bat'ková et al., 2008), commonly exposed to various stressing agents during culture (Gaspar et al., 2002; Hazarika 2006). In this paper, two olive callus lines, characterized by a different proliferation pattern, were analyzed for growth performances and biochemical traits linked to cell oxidative status. Friable-type callus proliferation pattern was associated to a remarkable higher growth rate compared with compact-type one while no difference in MDA content between the two callus lines was observed, indicating a similar lipid peroxidation status. In literature, modifications of the morphological aspect, growth and lipid peroxide content are commonly reported in callus cultures exposed to different stressing agents (Vieira Santos et al., 2001; Zacchini \& de Agazio, 2004b; Shekhawat et al., 2010; Iori et al., 2012).

A notable difference in hydrogen peroxide content occurred in the two callus lines, being higher in compact-type calli. Hydrogen peroxide, besides to be an oxidative stress agent, very toxic for cellular macromolecules like nucleic acids, proteins and lipids, can also play a role in stress signaling, stimulating the antioxidative defense system (Foyer \& Noctor, 2005; Quan et al., 2008) and the acclimation to stress (Azevedo Neto et al., 2005). In this context, the higher activity of the main antioxidative enzymes found in compact-type calli, concomitant with the higher hydrogen peroxide content, is consistent with results reported by several authors on callus cultures of different plant species (Tian et al., 2003; Zacchini \& de Agazio, 2004b; Song et al., 2006).

Concerning free PAs, the higher Put level found in friable-type calli, in comparison to compact ones, could be associated to both a protective role against stress factors occurring in culture and a regulative function in the cell morphogenesis. In fact, an involvement of Put in the tolerance to abiotic stress has been extensively reported (Bouchereau et al., 1999; 
Pintó-Marijuan et al., 2007; Gill \& Tuteja, 2010). Putrescine has been also claimed to play a protective role against oxidative stress in callus cultures (Zacchini \& de Agazio, 2004b; Tang $\&$ Newton, 2005). Further, an involvement of Put in the recovery of pine callus culture from tissue browning and in the improvement of plant regeneration has been reported (Tang et al., 2004). On the other hand, the capability of PAs in promoting and sustaining cell proliferation (Bais \& Ravishankar, 2002; Kuznetsov et al., 2006) and a relation between Put and growth of tissue cultures (Silveira et al., 2004; Steiner et al., 2007) have been described.

Compact-type calli showed a higher content of chlorophylls and carotenoids than friable-type ones. Modulation of the pigment content in in vitro culture plant cells due to the peculiar microenvironmental factors has been reported (Gaspar et al., 2002). Carotenoids has been recognized as one of the most abundant group of lipid-soluble antioxidants in plant cell (DellaPenna \& Pogson, 2006; Sharma et al., 2012) and the higher content in compact-type calli is consistent with their higher antioxidant enzyme activity.

In conclusion, results of this work put in evidence that olive in vitro cell proliferation can occur with different patterns involving growth, morphological characteristics and modulation of biochemical traits linked to cell oxidative status. Further studies are needed to evaluate whether the different proliferation patterns may be associated to a different regeneration potential of olive callus cultures.

\section{References}

Azevedo Neto, A. D., Prisco, J. T., Eneas-Filho, J., Medeiros, J-V. R., \& Gomes-Filho, E. (2005). Hydrogen peroxide pre-treatment induces salt-stress acclimation in maize plants. Journal of Plant Physiology, 162, 1114-1122. http://dx.doi.org/10.1016/j.jplph.2005.01.007

Bais, H. P., \& Ravishankar, G. A. (2002). Role of polyamines in the ontogeny of plants and their biotechnological applications. Plant Cell, Tissue and Organ Culture, 69, 1-34. http://dx.doi.org/10.1023/A:1015064227278

Bat'ková, P., Pospíšilová, J., \& Synková, H. (2008). Production of reactive oxygen species and development of antioxidative systems during in vitro growth and ex vitro transfer. Biologia Plantarum, 52, 413-422. http://dx.doi.org/10.1007/s10535-008-0085-5

Benson, E. E. (2000a). Do free radicals have a role in plant tissue culture recalcitrance? In Vitro Cell \& Developmental Biology- Plant, 36, 163-170. http://dx.doi.org/10.1007/s11627-000-0032-4

Benson, E. E. (2000b). In vitro plant recalcitrance: an introduction. In Vitro Cell \& Developmental Biology- Plant, 36, 141-148. http://dx.doi.org/10.1007/s11627-000-0029-z

Bouchereau, A., Aziz, A., Larher, F., \& Martin-Tanguy, J. (1999). Polyamines and environmental challenges: recent development. Plant Science, 140, 103-125. http://dx.doi.org/ 10.1016/S0168-9452(98)00218-0

Bradford, M. M. (1976). A rapid and sensitive method for the quantitation of microgram quantities of protein utilizing the principle of protein-dye binding. Analytical Biochemistry, 
72, 248-254. http://dx.doi.org/10.1016/0003-2697(76)90527-3

Cassells, A. C., \& Curry, R. F. (2001). Oxidative stress and physiological, epigenetic and genetic variability in plant tissue culture: implications for micropropagators and genetic engineers. Plant Cell, Tissue and Organ Culture, 64, 145-157. http://dx.doi.org/10.1023/A:1010692104861

Chance, B., \& Maehly, C. (1955). Assay of catalase and peroxidases. Methods in Enzymology, 11, 764-775. http://dx.doi.org/10.1016/S0076-6879(55)02300-8

DellaPenna, D., \& Pogson, B. J. (2006). Vitamin Synthesis in Plants: Tocopherols and Carotenoids. Annual Review Plant Biology, 57, 711-738. http://dx.doi.org/10.1146/annurev.arplant.56.032604.144301

Foyer, C. H., \& Halliwell, B. (1976). The presence of glutathione and glutathione reductase in chloroplasts: a proposed role in ascorbic acid metabolism. Planta, 133, 21-25. http://dx.doi.org/10.1007/BF00386001

Foyer, C. H., \& Noctor, G. (2005). Redox homeostasis and antioxidant signaling: A metabolic interface between stress perception and physiological responses. Plant Cell, 17, 1866-1875. http://dx.doi.org/10.1105/tpc.105.033589

Franck, T., Kevers, C., \& Gaspar, T. (1995). Protective enzymatic system against activated oxygen species compared in normal and hyperhydric shoots of Prunus avium L. raised in vitro. Plant Growth Regulation, 16, 253-256. http://dx.doi.org/10.1007/BF00024782

Franck, T., Kevers, C., Penel, C., Greppin, H., Hausman, J. F., \& Gaspar, T. (1998). Reducing properties, and markers of lipid peroxidation in normal and hyperhydrating shoots of Prunus avium L. Journal of Plant Physiology, 153, 339-346. http://dx.doi.org/10.1016/S0176-1617(98)80160-0

Galiba, G., Kocsy, G., Kaur-Sawhney, R., Sutka, J., \& Galston, A. W. (1993). Chromosomal localization of osmotic and salt stress-induced differential alterations in polyamine content in wheat. Plant Science, 92, 203-211. http://dx.doi.org/10.1016/0168-9452(93)90207-G

Gaspar, T., Franck, T., Bisbis, B., Kevers, C., Jouve, C., Hausmann, J. F., \& Dommes, J. (2002). Concepts in plant stress physiology. Application to plant tissue cultures. Plant Growth Regulation, 37, 263-285. http://dx.doi.org/10.1023/A:1020835304842

Gentile, L., \& Uccella, N. A. (2014). Selected bioactives from callus cultures of olives (Olea europaea L. var. Coratina) by LC-MS. Food Research International, 55, 128-136. http://dx.doi.org/10.1016/j.foodres.2013.10.046

Gill, S. S., \& Tuteja, N. (2010). Polyamines and abiotic stress tolerance in plants. Plant Signaling \& Behavior, 5, 26-33. http://dx.doi.org/10.4161/psb.5.1.10291

Grzelak, A., Rychlik, B., \& Baptosz, G. (2001). Light-dependent generation of reactive oxygen species in cell culture media. Free Radical Biology and Medicine, 30, 1418-1425. http://dx.doi.org/10.1016/S0891-5849(01)00545-7 
Havir, E. A., \& McHale, N. A. (1987). Biochemical and developmental characterization of multiple forms of catalase in tobacco leaves. Plant Physiology, 84, 450-455. http://dx.doi.org/10.1104/pp.84.2.450

Hazarika, B. N. (2006). Morpho-physiological disorders in in vitro culture of plants. Scientia Horticulturae, 108, 105-120. http://dx.doi.org/10.1016/j.scienta.2006.01.038

Heath, R. L., \& Packer, L. (1968). Photoperoxidation in isolated chloroplasts: I. Kinetics and stoichiometry of fatty acid peroxidation. Archives of Biochemistry and Biophysics, 125, 189-198. http://dx.doi.org/10.1016/0003-9861(68)90654-1

Hernández, M. L., Guschina, I. A., Martínez-Rivas, J. M., Mancha, M., \& Harwood, J. L. (2008). The utilization and desaturation of oleate and linoleate during glycerolipid biosynthesis in olive (Olea europaea L.) callus cultures. Journal of Experimental Botany, 59, 2425-2435. http://dx.doi.org/10.1093/jxb/ern121

Iori, V., Pietrini, F., \& Zacchini, M. (2012) Assessment of ibuprofen tolerance and removal capability in Populus nigra L. by in vitro culture. Journal of Hazardous Materials, 229-230, 217-223. http://dx.doi.org/10.1016/j.jhazmat.2012.05.097

Kuznetsov, Vl. V., Radyukina, N. L., Shevyakova, N. I. (2006). Polyamines and stress: biological role, metabolism, and regulation. Russian Journal of Plant Physiology, 53, 658-683. http://dx.doi.org/10.1134/S1021443706050025

Lichtenthaler, H. K. (1987). Chlorophyll and carotenoids: pigments of photosynthetic membranes. Methods in Enzymology, 148, 350-382. http://dx.doi.org/10.1016/0076-6879(87)48036-1

Nakano, Y., \& Asada, K. (1981). Hydrogen peroxide is scavenged by ascorbate-specific peroxidase in spinach chloroplasts. Plant Cell Physiology, 22, 867-880.

Pintó-Marijuan, M., de Agazio, M., Zacchini, M., Santos, M. A., Torné, J. M. , \& Fleck I. (2007). Response of transgluminase activity and bound putrescine to changes in light intensity under natural or controlled conditions in Quercus ilex L. leaves. Physiologia Plantarum, 131, 159-169. http://dx.doi.org/10.1111/j.1399-3054.2007.00939.x

Quan, L-J., Zhang, B., Shi, W-W., \& Li, H-Y. (2008). Hydrogen peroxide in plants: a versatile molecule of the reactive oxygen species network. Journal of Integrative Plant Biology, 50, 2-18. http://dx.doi.org/10.1111/j.1744-7909.2007.00599.x

Ramli, U. S., Baker, D. S., Quant, P. A., \& Harwood, J. L. (2002). Control mechanisms operating for lipid biosynthesis differ in oil-palm (Elaeis guineensis Jacq.) and olive (Olea europaea L.) callus cultures Biochemical Journal, 364, 385-391. http://dx.doi.org/10.1042/BJ20010202

Rugini, E. (1984). In vitro propagation of some olive (Olea europaea var. sativa L.) cultivars with different root-ability, and medium development using analytical data from developing shoots and embryos. Scientia Horticolturae, 24, 123-134. http://dx.doi.org/10.1016/0304-4238(84)90143-2 
Rugini, E., \& Caricato, G. (1995). Somatic embryogenesis and plant recovery from mature tissues of olive cultivars (Olea europea L.) "Canino" and "Moraiolo". Plant Cell Reports, 14, 257-260. http://dx.doi.org/10.1007/BF00233645

Rugini, E., Biasi, R., \& Muleo, R. (2000). Olive (Olea europea var. sativa) transformation. In S. M. Jain \& S. C. Minocha (Eds.). Dordrecht Molecular Biology of Woody Plants (pp. 245-279), Kluwer Academic Publishers.

Saimaru, H., Orihara, Y., Tansakul, P., Kang, Y-H., Shibuya, M., \& Ebizuka Y. (2007). Production of triterpene acids by cell suspension cultures of Olea europaea. Chemical and Pharmaceutical Bulletin, 55, 784-788. http://dx.doi.org/10.1248/cpb.55.784

Sharma, P., Jha, A. B., Dubey, R. S., \& Pessarakli, M. (2012). Reactive oxygen species, oxidative damage, and antioxidative defense mechanism in plants under stressful conditions. Journal of Botany, 2012. http://dx.doi.org/10.1155/2012/217037

Shekhawat, G. S., Verma, K., Jana. S., Singh, K., Teotia, P., \& Prasad, A. (2010). In vitro biochemical evaluation of cadmium tolerance mechanism in callus and seedlings of Brassica juncea. Protoplasma, 239, 31-38. http://dx.doi.org/10.1007/s00709-009-0079-y

Shibli, R. A., \& Al-Juboory, K. (2002). Comparative Responses of "Nabali" olive microshoot, callus, and suspension cell cultures to salinity and water deficit. Journal of Plant Nutrition, 25, 61-74. http://dx.doi.org/10.1081/PLN-100108780

Silveira, V., Floh, E. I. S., Handro, W., \& Guerra, M. P. (2004). Effect of plant growth regulators on the cellular growth and levels of intracellular protein, starch and polyamines in embryogenic suspension cultures of Pinus taeda. Plant Cell, Tissue and Organ Culture, 76, 53-60. http://dx.doi.org/10.1023/A:1025847515435

Song, L., Ding, W., Zhao, M., Sun, B., \& Zhang, L. (2006). Nitric oxide protects against oxidative stress under heat stress in the calluses from two ecotypes of reed. Plant Science, 171, 449-458. http://dx.doi.org/10.1016/j.plantsci.2006.05.002

Steiner, N., Santa-Catarina, C., Silveira, V., Floh, E. I. S., \& Guerra, M. P. (2007). Polyamine effects on growth and endogenous hormones levels in Araucaria angustifolia embryogenic cultures. Plant Cell, Tissue and Organ Culture, 89, 55-62. http://dx.doi.org/10.1007/s11240-007-9216-5

Tang, W., Newton, R. J., \& Outhavong, V. (2004). Exogenously added polyamines recover browning tissues into normal callus cultures and improve plant regeneration in pine. Physiologia Plantarum, 122, 386-395. http://dx.doi.org/10.1111/j.1399-3054.2004.00406.x

Tang, W., \& Newton, R. J. (2005). Polyamines reduce salt-induced oxidative damage by increasing the activities of antioxidant enzymes and decreasing lipid peroxidation in Virginia pine. Plant Growth Regulation, 46, 31-43. http://dx.doi.org/10.1007/s10725-005-6395-0

Tian, M., Gu, Q., \& Zhu, M. (2003).The involvement of hydrogen peroxide and antioxidant enzymes in the process of shoot organogenesis of strawberry callus. Plant Science, 165, 701-707. http://dx.doi.org/10.1016/S0168-9452(03)00224-3 


\section{Macrothink}

Trabelsi, E. B., Naija, S., Elloumi, N., Belfeleh, Z., Msellem, M., Ghezel, R., \& Bouzid, S. (2011). Somatic embryogenesis in cell suspension cultures of olive Olea europaea (L.) 'Chetoui'. Acta Physiologia Plantarum, 33, 319-324. http://dx.doi.org/10.1007/s11738-010-0550-6

Vieira Santos, C. L., Campos, A., Azevedo, H., \& Caldeira G. (2001). In situ and in vitro senescence induced by $\mathrm{KCl}$ stress: nutritional imbalance, lipid peroxidation and antioxidant metabolism. Journal of Experimental Botany, 52, 351-360. http://dx.doi.org/10.1093/jexbot/52.355.351

Wellburn, A. R. (1994). The spectral determination of chlorophylls $a$ and $b$, as well as total carotenoids, using various solvents with spectrophotometers of different resolution. Journal of Plant Physiology, 144, 307-313. http://dx.doi.org/10.1016/S0176-1617(11)81192-2

Williams, M., Sanchez, J., Hann, A. C., \& Harwood, J. L. (1993). Lipid biosynthesis in olive cultures. Journal of Experimental Botany, 44, 1717-1723. http://dx.doi.org/10.1093/jxb/44.11.1717

Williams, M., Morales, M. T., Aparicio, R., \& Harwood, J. L. (1998). Analysis of volatiles from callus cultures of olive Olea Europaea. Phytochemistry, 47, 1253-1259. http://dx.doi.org/10.1016/S0031-9422(97)00730-9

Williams, M., Salas, J. J., Sanchez, J., \& Harwood, J. L. (2000). Lipoxygenase pathway in olive callus cultures (Olea europaea). Phytochemistry, 53, 13-19. http://dx.doi.org/10.1016/S0031-9422(99)00468-9

Zacchini, M., \& de Agazio, M. (2004a). Micropropagation of a local olive cultivar for germplasm preservation. Biologia Plantarum, 48, 589-592. http://dx.doi.org/10.1023/B:BIOP.0000047156.57328.27

Zacchini, M., \& de Agazio, M. (2004b). Spread of oxidative damage and antioxidative response through cell layers of tobacco callus after UV-C treatment. Plant Physiology and Biochemistry, 42, 445-450. http://dx.doi.org/10.1016/j.plaphy.2004.03.007

\section{Copyright Disclaimer}

Copyright reserved by the author(s).

This article is an open-access article distributed under the terms and conditions of the Creative Commons Attribution license (http://creativecommons.org/licenses/by/3.0/). 